Egypt. Acad. J. Biolog. Sci., 5 (2): 7 -13 (2013)

Email: egyptianacademic@yahoo.com

Received: 21 / 3 / 2011
F. Toxicology \&Pest control

ISSN: 2090 - 0791

www.eajbs.eg.net

\title{
Controlling of cotton leafworm using some manufacturing Botanical formulations
}

\author{
Amal A. Abd-Allah ${ }^{1}$;Sondos A. Mohamed ${ }^{1}$ Ahmed.G.El-Sisi $^{2}$; \\ 1-Plant Protection Research Institute, ARC, Dokki, Giza \\ 2-. Central Agricultural Pesticides Laboratory, ARC, Dokki, Giza
}

\begin{abstract}
Three synthetic botanical materials which are Camphour, Menthol and Thymol were prepared as suitable fromulations: Camphour as $25 \%$ emulsifable concentrate, both Menthol and Thymol as 20\% concentrated emulion. Prepared formulations sprayed on tomato plants at concentrations 1.0, 1.5 and $2.0 \%$ (V. /V.). Direct effect on present $2^{\text {nd }}$ and $4^{\text {th }}$ instar larvae of cotton leafworm was determined by takeing tomato leaves samples directly after spraying and introducing these leaves samples to larvae in laboratory, for studying latent effect,treated leaves samples were taken each two days and introduced to the rest alive larvae,mortality counts was recorded each two days,then mortality percentages were calculated.Residual effect was determined by the same method mentioned before, by taking leaves samples after 7 days of treatment and introduchngto larvae in laboratory, other samples taken each two days and introduced to the rest alive larvae. Antifeedent effect also was determined by determination the consumed amount of treated tomato leaves and untreated, then reduction percentage in food consumed was calculated. Results obtained indicated that the tested matrials at all tested concentrations showed hightoxic effect directly against the present larvae or residual after7days against new infestation if occurred .Also, the tested materials showed antifeedent effect against $4^{\text {th }}$ instar larvae to be more than $50 \%$ at $1 \%$ concentration. For economic consideration,concentration $1 \%$ could be recommended for controlling larvae of cotton leafworm infested tomato.
\end{abstract}

Keywords: cotton leafworm - Botanical formulations - control

\section{Tomato}

(LycopersiconesculentumL.) is an important vegetable crop grown in Egypt. It attacked by several insect pests such as Bemisiatabaci Genn., Aphis gossypii Glover, Myzuspersica Sulzer, Thripstabaci Lind, Empoasca spp., Spodopteralittoralis Bosid., and Liriomyza Sp. (Ahmad 2006).

Among of these insects the cotton leafwormSpodopteralittoralis (Boisd) is a polyphagous insect, is akey pest of cotton and other crop in the Mediterranean area and middle eastern countries (Campion et al., 1977; GomezClemente and Delrivero, 1951; Nasr et al., 1984; Ahmad, 1988; Dominguez, 1993) known to infest approximately 112 host plants belonging to different families.

Awide range of chemicals have been marketing for controlling pests because its effectiveness and speed controlling of insect pests (Omar et al., 1996, Elfakharany 2005). Also plant oil was used because cheaper and more safe to human and environment Abd-Elaziz et al., (2002) El fakharany (2005 and 2010) Appiagyei (2010) and Mochiah et al., (2011) indicated the effect of petroleum oil and plant oil against insect pests and predators. 
Therefore, the aim of the present work was to evaluate the efficiency of these three manufacturing botanical formulations (Camphour, Menthol and Thynol) for controlling $S$.littoralis in addition to evaluate the residual effect of these treatment against $2^{\text {nd }}$ and $4^{\text {th }}$ instar larvae of cotton leafworm.

\section{MATERIALS AND METHODS}

The present work was conducted to study both direct and latent effect of three manufacturing botanical formulations on both $2^{\text {nd }}$ and $4^{\text {th }}$ instar larvae of cotton leafwormSpodopteralittoralis (Boisd).

Manufacturing potenical formulation

Camphour 99\%: is a waxy,white or transparent solid with a strong odor. It is a terpenoid.

Chemical name: IUPAC name: 1,7,7Trimethylbiocylo (2.2.1) heptanes.

Chemical formula: $\mathrm{C}_{10} \mathrm{H}_{16} \mathrm{O}$.

It was supplied from Gomhoria Company, Cairo.

Menthol 99\%: (Mentapulegyium L. (Mint). Is an organic compound made synthetically, it is a waxy crystalline substrate, clear or white in color, which is solid at room temperature.

Chemical name : IUPAC name : ( 1R,2,5,5R ) -2-isopropyl-5-cyclohexanol Chemical formula: $\mathrm{C}_{10} \mathrm{H}_{20} \mathrm{O}$.

Productive Company: SDFCL (sd FineChem Limited), India.

Thymol 99\%: It is a natural monoterpene phenol.white crystalline substrate of a pleasant aromatic odor.

Chemical name: 2- isopropyl-5-methyl phenol.

Chemical formula: $\mathrm{C}_{1 \mathrm{o}} \mathrm{H}_{14} \mathrm{O}$.

Productive Company: ALPHA

CHEMIKA, India.

Preparation of the botanical materials as formulations:

Laboratory tests for the above materials indicated that they did not soluble in water, but they soluble in xylene solvent at ratio $40 \%$ (weight/volume), therefore they were preparedemulsifiable concentrate or concentrated emulsion. Camphour prepared as $25 \%$ emulsifiable concentrate by dissolving 25 g.camphour in $70 \mathrm{ml}$. xylene then emulsifierpolyethyleneglycol 600 mono laurate was add at rate $5 \%$, while both menthol and thyamol were prepared as concentrated emulsion by dissolving $20 \mathrm{~g}$.of active ingredient in $55 \mathrm{ml}$.xylene then $25 \mathrm{ml}$. of emulisifier potassium polyaryl alkyl sulfonate solution in water was add and mix well.

\section{Reared culture:}

Alaboratory reared culture of cotton leafworm according El-defrawi et al., (1964) was used synchronized second instars larvae were choose for the experiment.

The insecticidal activity of these three treatments was assessed on $2^{\text {nd }}$ and $4^{\text {th }}$ instars larvae of $S$. littoralis three concentration 20,15 and $10 \mathrm{ml} /$ liter were used for each manufacturing potenical formulations.

\section{Expermintal design:}

The experiment was conducted according to Ministry of Agriculture Protocol(1993) and Mohmed et al., (2001).In 2013 tomato grown field at Banha district, Qalubyia Governorate. The experiment area which was 4 kerate were divided into three plots (one for each treatment). In addition to 1 kerate for untreated control, each plot was divided into three for each concentration.

\section{Procedures of evaluation:}

Initial and latent toxicity against larvae of cotton leafworm:

This experiment represents the effect against present infestation which was carried out by taking tomato leaves samples directly after spraying when plant became dry then treated leaves were transferred to the laboratory and introduced to $2^{\text {nd }}$ and $4^{\text {th }}$ instar larvae of cotton leafworm,Spodopteralittoralis (Boisd). Under constant conditions of $25^{\circ} \mathrm{C} \pm 1$ and $70 \pm 5 \%$ RH.three replicate for each treatment each have 15 larvae. For studying the latent effect against 
treated leaves other samples were taken each 2 days from field continuously and introduced to the rest alive larvae.

Mortality count was recorded each 2days then mortality percentages were calculated.

Residual activity of different treatment against larvae of cotton leaf worm: Tomato leaves samples were taken after 7 days of spraying and introduced to $2^{\text {nd }}$ and $4^{\text {th }}$ instar larvae in laboratory, other samples were taken each two days and introduced to the rest alive larvae. Mortality count were recorded each 2days then mortality percentages were calculated.

Antifeedent effect of the different treatment against $4^{\text {th }}$ instar larvae of cotton leaf worm: New moulted $4^{\text {th }}$ instar larvae were fed on tomato leaves accurately weighed, previously dipped in concentration $2,1,0.5$ and $0.25 \%$ for each material compared with control which fed on untreated leaves, 3 replicate each have 15 larvae. After 24 hrs. of feeding ,the rest leaves were weighedin each replicate, then consumped of amount of leaves were calculated and antifeedent effect were calculated as Waldbouer (1968) equation Antifeedent:
$\%$ Reduction in food consumption

$$
=\frac{\mathrm{Cc}-\mathrm{Ct}}{\mathrm{Cc}} \times 100
$$

Where:

$\mathrm{Cc}=$ Cosumped amount in untreated $\mathrm{Ct}=$ Consumped amount in treated

\section{RESULTS AND DISCUSSION}

The insecticidal efficiency in this study includes studying both toxicity and antifeedent effectof the tested materials.

Toxicity of the tested botanical formulations against larvae of cotton leafworm.

Toxicity against present infestation:

Results shown in Table 1 about the toxicity against $2^{\text {nd }}$ instar larvae and in table 2 about the toxicity against $4^{\text {th }}$ instar larvae of cotton leafworm indicated that: the toxicity increased as both concentration and period of feeding with treated leaves increased. It showed be said there are different between different concentrations in toxicity after 2 days of feeding, this differentiation in toxicity increased after 4days of feeding to reach the same effect ( $100 \%$ mortality $)$ after 6 days of feeding. Also, indicated that there are already similar toxicity between $2^{\text {nd }}$ and $4^{\text {th }}$ instar larvae.

Table 1: Insecticidal efficiency of the tested materials against $2^{\text {nd }}$ instar larvae of cotton leafworm infested tomato leaves.

\begin{tabular}{|c|c|c|c|c|}
\hline \multirow{2}{*}{ Treatments } & \multirow{2}{*}{ Conc. \% (V./V.) } & \multicolumn{3}{|c|}{$\%$ Mortalities after indicated days of exposure } \\
\cline { 2 - 5 } & & 2 & 4 & 6 \\
\hline \multirow{3}{*}{ Camphour } & 1.00 & 37.78 & 77.68 & 100 \\
\cline { 2 - 5 } & 1.50 & 55.56 & 81.11 & 100 \\
\cline { 2 - 5 } & 2.00 & 71.11 & 84.44 & 100 \\
\hline \multirow{3}{*}{ Menthol } & 1.00 & 35.56 & 88.98 & 100 \\
\cline { 2 - 5 } & 1.50 & 60.00 & 97.00 & 100 \\
\cline { 2 - 5 } & 2.00 & 77.78 & 97.78 & 100 \\
\hline \multirow{3}{*}{ Thymol } & 1.00 & 55.56 & 91.11 & 100 \\
\cline { 2 - 5 } & 1.50 & 71.11 & 95.56 & 100 \\
\cline { 2 - 5 } & 2.00 & 80.00 & 97.00 & 100 \\
\hline Untreated & & 0.00 & 5.00 & 9.00 \\
\hline
\end{tabular}


Table 2: Insecticidal efficiency of the tested materials against $4^{\text {th }}$ instar larvae of cotton leafworm infested tomato leaves.

\begin{tabular}{|c|c|c|c|c|}
\hline \multirow{2}{*}{ Treatments } & \multirow{2}{*}{ Conc. \% (V.IV.) } & \multicolumn{3}{|c|}{$\%$ Mortalities after indicated days of exposure } \\
\cline { 2 - 5 } & 1.00 & 2 & 4 & 6 \\
\hline \multirow{3}{*}{ Camphour } & 1.50 & 26.67 & 71.11 & 100 \\
\cline { 2 - 5 } & 2.00 & 71.33 & 82.56 & 100 \\
\cline { 2 - 5 } & 1.00 & 40.00 & 93.33 & 100 \\
\hline \multirow{3}{*}{ Menthol } & 1.50 & 60.00 & 75.56 & 100 \\
\cline { 2 - 5 } & 2.00 & 80.11 & 86.68 & 100 \\
\cline { 2 - 5 } & 1.00 & 31.11 & 64.33 & 100 \\
\hline \multirow{3}{*}{ Thymol } & 1.50 & 42.11 & 80.44 & 100 \\
\cline { 2 - 5 } & 2.00 & 51.22 & 93.00 & 100 \\
\cline { 2 - 5 } & & 0.00 & 6.11 & 100 \\
\hline Untreated & & & & 9.00 \\
\hline
\end{tabular}

Residual effect: Results in table 3 about the residual toxicity after 7days of spray against $2^{\text {nd }}$ instar larvae in table 4 against $4^{\text {th }}$ instar larvae indicated that the effect increased as concentration and period of feeding with treated leaves increased to be $100 \%$ mortality after 4days of feeding for all tested materials at all tested concentrations. Results of direct toxicity and residual toxicity indicated that the materials showed high direct and residual toxicity against two tested instar larvae. This mean that spraying with this materials are effective against present infestation and new infestation after 7days of spraying. Results of toxicity for these botanical materials against larvae of cotton leaf worm. The results obtained agree with Abdel- All (2012) who studied the effect of four plant oils Mentha Pluegium, Onion, Mustard and Garlic in controlling cotton leafworm, Spodopteralittoralis. Also, Abdel- Wahab (2002) who studied the biological and biochemical effect of some potenical extracts on cotton leafworm., El-Ghareeb (1992) found that Chlorfluazuorn was toxic than Diflubenzuron against $3^{\text {rd }}$ and $5^{\text {th }}$ instar larvae of Spodopteralittoralis in the laboratory. Also Bayoumi et al., (1998) found that $3^{\text {rd }}$ instar were more sensitive to Chlorfluazuron and Flufenoxuron, compared with $5^{\text {th }}$ instar of Spodopteralittoralis (Boisd). andIshaayaet al., (1995) indicated that Tebufenozide is potentially potent insecticide for controlling larvae of Spodopteralittoralis (Boisd).

Table 3: Residual activity of the tested materials against $4^{\text {th }}$ instar larvae of cotton leavewrm infested tomato leave after 7 days of treatment.

\begin{tabular}{|c|c|c|c|c|}
\hline \multirow{2}{*}{ Treatments } & \multirow{2}{*}{ Conc. \% (V.IV.) } & \multicolumn{3}{|c|}{$\%$ Mortalities after indicated days of exposure } \\
\cline { 2 - 5 } & & 2 & 4 & 6 \\
\hline \multirow{3}{*}{ Camphour } & 1 & 28.89 & 56.11 & 100 \\
\cline { 2 - 5 } & 1.5 & 44.44 & 72.66 & 100 \\
\cline { 2 - 5 } & 2 & 54.22 & 80 & 100 \\
\hline \multirow{3}{*}{ Menthol } & 1 & 37.11 & 66.66 & 100 \\
\cline { 2 - 5 } & 1.5 & 51.78 & 72 & 100 \\
\cline { 2 - 5 } & 2 & 62.11 & 87.11 & 100 \\
\hline \multirow{3}{*}{ Thymol } & 1 & 53.89 & 60 & 100 \\
\cline { 2 - 5 } & 1.5 & 58.33 & 74.11 & 100 \\
\cline { 2 - 5 } & 2 & 62.22 & 80 & 100 \\
\hline Untreated & & 0 & 5 & 10 \\
\hline
\end{tabular}


Table 4: Residual activity of the tested materials against $4^{\text {th }}$ instar larvae of cotton leavewrm infested tomato leave after 7 days of treatment.

\begin{tabular}{|c|c|c|c|c|}
\hline \multirow{2}{*}{ Treatments } & \multirow{2}{*}{ Conc.\% (V.IV.) } & \multicolumn{3}{|c|}{$\%$ Mortalities after indicated days of exposure } \\
\cline { 2 - 5 } & & 2 & 4 & 6 \\
\hline \multirow{3}{*}{ Camphour } & 1.00 & 17.78 & 60.00 & 89.11 \\
\cline { 2 - 5 } & 1.50 & 42.22 & 70.66 & 90.00 \\
\cline { 2 - 5 } & 2.00 & 50.00 & 80.00 & 90.00 \\
\hline \multirow{3}{*}{ Menthol } & 1.00 & 15.55 & 55.66 & 80.00 \\
\cline { 2 - 5 } & 1.50 & 35.11 & 63.44 & 90.22 \\
\cline { 2 - 5 } & 2.00 & 51.11 & 72.11 & 92.66 \\
\hline \multirow{3}{*}{ Thymol } & 1.00 & 15.56 & 66.12 & 97.11 \\
\cline { 2 - 5 } & 1.50 & 35.56 & 74.11 & 98.11 \\
\hline Untreated & 2.00 & 54.11 & 81.44 & 96.44 \\
\hline
\end{tabular}

Antifeedent effect: Results in table 5 about the antifeedent effect of the tested botanical materials against $4^{\text {th }}$ instar larvae, the most seriously instar in feeding, indicated that all tested concentrations decreased the amount of food consumption than untreated, and this effect was increased as concentration increased, therefore, $\%$ antifeedent which expressed $\%$ reduction in food consumption which mean protection of treated plant from feeding with this harm stage increase as concentration increased to be more than $50 \%$ at $1 \%$ concentration. Results of antifeeedent effect against larvae of cotton leafworm are agree with El-Gengahi et al., (1996) who found a significant reduction in the food consumed and a considerable decrease in the body weight gained by the larvae Spodopteralittoralis (Boisd) and Agrotisipsilon offered caster bean leaves treated with different plant extracts. Also Benard et al., (1991) found that the growth rate of Spodopteralittoralis treated with Cyfluthrin was reduced and reduction in weight gain was not compensated until the end of the $4^{\text {th }}$ instar.

Table 5: Antifeedant effect of the tested materials against $4^{\text {th }}$ instar larvae of cotton leafworm.

\begin{tabular}{|c|c|c|c|}
\hline Treatment & Conc. \% (V.ıV.) & Consumped food (g.) & \% Antifeedant \\
\hline \multirow{4}{*}{ Camphour } & 2.5 & 4.08 & 29.90 \\
\cline { 2 - 4 } & 5.0 & 3.52 & 39.52 \\
\cline { 2 - 4 } & 10.0 & 3.82 & 51.87 \\
\cline { 2 - 4 } & 20.0 & 2.58 & 55.67 \\
\hline \multirow{4}{*}{ Menthol } & 2.5 & 3.21 & 46.39 \\
\cline { 2 - 4 } & 5.0 & 2.55 & 56.19 \\
\cline { 2 - 4 } & 10.0 & 3.38 & 41.92 \\
\hline \multirow{3}{*}{ Thymol } & 20.0 & 2.70 & 53.61 \\
\cline { 2 - 4 } & 2.5 & 3.77 & 35.22 \\
\cline { 2 - 4 } & 5.0 & 3.49 & 40.03 \\
\cline { 2 - 4 } & 10.0 & 2.83 & 51.37 \\
\hline Untreated & 20.0 & 2.38 & 59.11 \\
\hline
\end{tabular}

Where:

$\mathrm{C}=$ Comsumped food in untreated.

$\mathrm{T}=$ Comsumped food in treated.

Conclusion: The tested botanical formulation showed both toxic effects directly against present infestation, or residual after 7 days of spraying against new infestation and also showed antifeedent effects against larvae of cotton leafworm. All concentrations, 
considered be successful for controlling this stage of cotton leafworm, but for economic consideration, concentration of $1 \%$ could be recommended.

\section{REFERENCES}

Abdel-All, E. Aziza (2012): The efeect of four oils in controlling Spodopteralittoralis larvae s (Boisd). Egypt. J. Agric. Res., 90 (2):187-197.

Abdel-Wahab, H.H.(2002): Biological and biochemical studies on the effect of some botanical extracts on cotton leafwormSpodopteralittoralis (Boisd) M. Sc. Thesis, Ain Shams Univ., Egypt.

Ahmad, T.R. (1988): Field studies on sex phermone trapping of cotton leafworm Spodopteralittoralis (Boisd), (Lepidoptera: Noctuidae). J. Appl. Entomol., 105: 212-215.

Ahmad, M.(2006): Survey of natural enemies associated with major insect pests of tomato crop in green house in the coastal areas of Syria. Regional integrated pest management (IPM) programme in the Near East final Report, (GTFS/REM/070ITA), Food and Agriculture organization of the united, Tishreen university Lattakia, Syria.

AbdEl-Aziz, S. Y.; S.A. Mohamed and S. Abdel-Wahab(2002): Efficiency of four seed plant oils for controlling certain pests in eggplant fields. $2^{\text {nd }}$ Int. Conf. Plant. Protect. Res. Instit. Cairo, Egypt, 21-24 December.

Appiagyei, F(2010): Effect of two neem Kernal extracts in the control of Whitefly (Bemisiatabaci) on tomato. M. Sc. Thesis, Kwame Nkrumah university of Science and Technology, pp98.

Bayoum, A.E.; Balana-Fouce, R.; Sobeiha, A. K. and Hussein, E. M. K. (1998): The biological activity of some chitin synthesis inhibitors against the leafworm Spodopteralittoralis (Boisd), (Lepidoptera: Noctuidae).Boletin de Sandidad vegetal, Plagas, vol.24, No. 3, pp.499-506, 21 ref.

Bernard, L.; Lagadic, L. and Echaubard, M. (1991): Effects of Cyfluthin on growth and food consumption in the $4^{\text {th }}$ larval instar of Spodopteralittoralis (Boisd), (Lepidoptera: Noctuidae). Mededelingen van de Facutteit Landbouwwet- enschappen, Rijksuniversiteit Gent, vol. 56, No. 3b, pp. 1089- 1097, 19 ref.

Campion, D. G.; Bettany, B. W.; Mcginnigle, J. B. and Tailor, L. R. (1977): The distribution and migration of the leafwormSpodopteralittoralis (Boisd), (Lepidoptera: Noctuidae). In relation to meteorology on Cyprus, interpreted from maps of pheromone trap samples. Bulletin of Entomology Research, 67: 501-522.

Dominguez, F. (1993): Plagasyenfermedades de lasplantascultivadas. Ediciones Mundi- Prensa Madrid. 821pp.

El-Dafrawi, M.; A., Tappozada; N., Mansour and M., Zeid (1964): Toxicological studies on the Egyptian cotton leafworm, Prodenialitura. I. Susceptibility of different larval instar to insecticides. J. Econ. Entomol. 57 (4) : 591-593.

El-Fakharany, S. K. M.(2005): Integrated control of some vegetable crops pests in Kafr El-Sheik Province. Ph.D. Thesis, Fac. Agric, Kafr El-Sheikh, Tanta univ., pp170.

El-Fakharany, S. K. M.(2010): Population Flactuation of Thrips, Whitefly and associated predators in cabbage plantations as influenced by factors and toxic compounds. J. Plant. Prpt.And Path., Mansoura univ., 1(11): 885-897.

El-Gengahi, S.c.; Ismail, I. A. and Atwa, G. (1996): Anti insect properties of the AntholyzaricngensAndr. (Family :Iridacae) extracts for ovicidal effect on the rice moth Corcyra cephalonica (Stainton). Pest, Management and Econ. Zoology 5 (1) 53-55.

El-Ghareeb, A. M. (1992): Comparative toxicity of some benzoylphenyl urea moltinhibiting insecticides to cotton leafworm Spodopteralittoralis (Boisd). Indian Journal of Entomology, vol. 54, no. 4, pp. 388-393, 15ref.

Gomez-Clemente, F. and Del- Rivero, J. M. (1951): La" rosquillanegra" (Prodenialituraf.). Boletin de pathology vegetal Entomology Agriculture, 19: 221-278

Ishaaya, I.; Yablonski, S.; Horowitz, A. R. (1995): Comparative toxicity of two ecdysteroid agonists, RH-2485 and RH5992, on Susceptible and pyrethroid resistant strains of Egyptainleafworm Spodopteralittoralis (Boisd). 
Ministry of Agriculture (1993): Protocoles of evaluation the efficiency in Egyptian cultures, pp.85.

Mochiah, M. B.; B. Banful; K.N., Fening; B. W., Amoabeng; K. OffeiBonsu; S. Skyem; H., Braimah and M. OwusuAkgaw(2011): Botanicals for the management of insect pests in organic vegetable production. J. Entomology and Nematology 3(6):85-97.

Mohmd, Sonds A.; A. G., El-Sisi and I. S., Abdel-Wahab (2001): Insecticidal activity of some foliar fertilizers against cotton leafwormSpodopteralittoralis (Boisd). J. Agric. Sci. Mansoura Univ., 26 (12): 8047-8052.

Nasr, E. A.; Tucker, M. R. and Campion, D. G. (1984): Distribution of moth of the
Egyptian cotton the leafworm Spodopteralittoralis (Boisd), (Lepidoptera: Noctuidae), in the Nile Delta interpreted from catches in aphermone trap Network in relation to meteorological factors. Bultetin of the Entomology Research, 74: 487-494.

Omar, H. I; H. M. El-Magharaby; M. H. M. El-Khawalka and M. A. ElBessomy(1996): Effects of different rates of the antifeeder, Pymetrozine on various stages of Whitefly(Bemisiatabaci) and Aphid on tomato plants. Alex. Sci. Exch., 17 (3): 2.

Waldbauer, G.P. (1968): The consumption and utilization of food by insect. Adv. Insect Physiol., 5.229-238.

\section{ARABIC SUMMARY}

\section{مكافحة دودة ورق القطن باستخدام مستحضرات نباتية محضرة صناعيا \\ أمل عبدالحليم عبدالله1 ـ سندس عبدالتواب محمد1 ـ أحمد غازي السيسي2

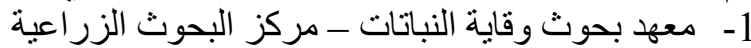

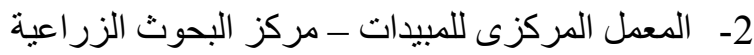

تـم تحضــير ثلاثـة مركبـات نباتبـة مخلقـة صــاعيا و هـي الكـافور ،المنتـول والثـايمول علـي صــورة

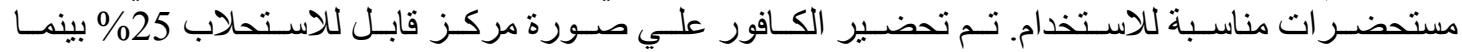

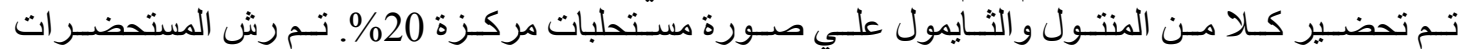

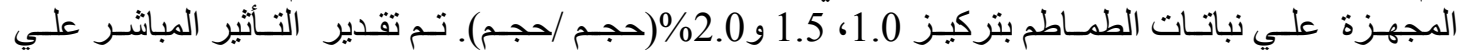

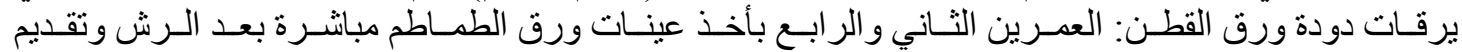

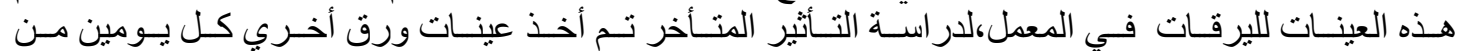

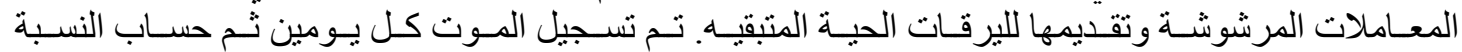

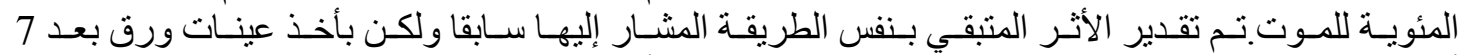

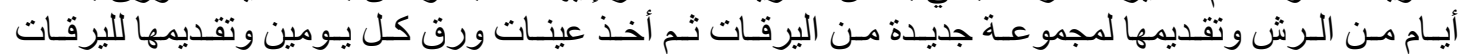

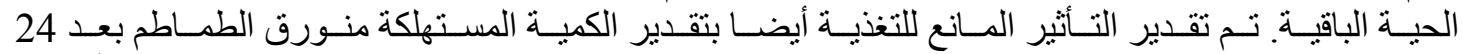

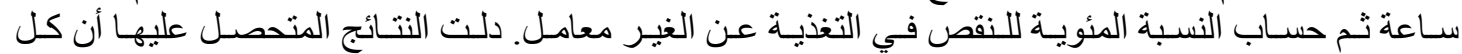

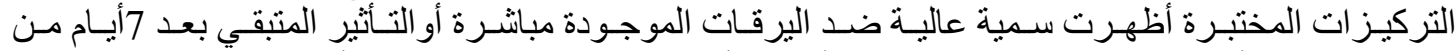

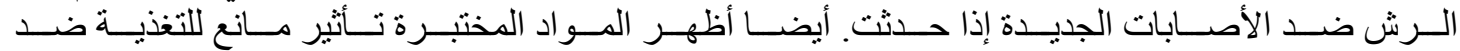

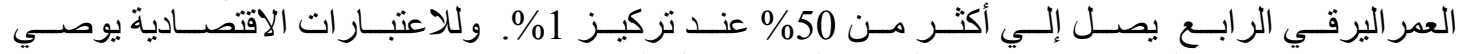
باستخدام تركيز 1\% لمكافحة دودة ورق القطن علي محصول الطماطم. 